\title{
Athens and the Achaemenid Persian Empire in 508/7 BC: Prologue to the Conflict
}

\author{
Eduard Rung \\ Kazan (Volga Region) Federal University, Institute of International Relations, \\ History and Oriental Studies, Russian Federation \\ Email: eduard_rung@mail.ru
}

\section{Doi:10.5901/mjss.2015.v6n3s2p257}

\section{Abstract}

The paper considers the beginning of the relations between Athens and the Achaemenid Persian Empire. It covers the crucial period of transition from Archaic to the Classical period in the Greek History as well as the time of the expansion of the Achaemenid Empire into the West. This paper deals primarily with the events from diplomatic history anticipated the GrecoPersian Wars. The material having been considered in this paper is significant for understanding of reasons for this first global conflict in the world history.

Keywords: Greeks, Persians, diplomacy, international relations, war, empire, polis.

\section{Introduction: Historical Situation}

This paper considers the reasons and circumstances of the Athenians' involvement into relations with the Persians for first time. In 540s the Persians proceeded to subdue the Greeks of Asia Minor, initially led by Harpagus and then by Mazares, both Cyrus' generals (Petit, 1985). Cambyses, son of Cyrus the Great, had the Ionians and the Aeolians as his subordinates when he led an expedition against Egypt in 526. Darius I who ascended the throne after Cambyses' death and assassination of usurper Gaumata in 523 , also controlled many Greek coastal cities which were situated inside the Persian Empire, not only in Asia, but in Europe, and subdued some Greek cities and islands (on Darius' attitude towards the Greeks: Cook, 1985; Young, 1988; Briant, 2002). He also installed tyrants from his loyal Greek supporters in a number of cities, which were under his control (Graf, 1985; Austin, 1990; Luraghi, 1998).

While the Spartans had remained on unfriendly terms with the Persians since Cyrus the Great, the Athenians, who were involved for a century in internal problems, principally Solon's reforms and tyranny of the Peisistratids, abstained from any contacts with the Persians until the reign of Darius I. Meanwhile the Athenians decided to have been involved into contacts with Achaemenid Persia in 508/7 B.C. The reasons and circumstances for this Athenian decision are clarified by the Herodotus' report.

\section{The First Athenian Embassy to Persia}

Herodotus (5. 73) writes on this Athenian embassy as follows:

"After that, the Athenians sent to bring back Cleisthenes and the seven hundred households banished by Cleomenes. Then, desiring to make an alliance with the Persians, they dispatched envoys to Sardis, for they knew that they had provoked the Lacedaemonians and Cleomenes to war. When the envoys came to Sardis and spoke as they had been bidden, Artaphrenes son of Hystaspes, viceroy of Sardis, asked them, "What men are you and where do you live, who desire alliance with the Persians?" When he had received the information he wanted from the envoys, he gave them an answer the substance of which was that if the Athenians gave king Darius earth and water, then he would make an alliance with them, but if not, his command was that they should depart. The envoys consulted together, and in their desire to make the alliance, they consented to give what was asked. They then returned to their own country and were there greatly blamed for what they had done" (translation by A.D. Godley).

So, Herodotus (5. 73) reports that the Athenians sent their envoys to Sardis only in 508/7 to negotiate an alliance with the Persians and thereby to prevent an anticipated Spartan invasion of Attica under king Cleomenes I, who wished to interfere in the factional strife in Athens on behalf of Isagoras, the political opponent of the great reformer Cleisthenes. J.A.R. Munro (1899) and Ed. Meyer (1958) made Cleisthenes responsible for the Athenian embassy to Sardis.

E.M. Walker (1930) considered that the family of Cleisthenes had already before maintained the various contacts 
with the East in the period of Lydian Kingdom. On his view, Cleisthenes himself was responsible for the dispatch this embassy, preferring to secure the cause of democracy even at the cost of submission to Persia. Walker noted that Cleisthenes who was possibly better acquainted with the circumstances of the Persian Empire than most people at Athens, should have imagine that Persian aid could be obtained on any other condition than that of giving earth and water, the symbols of homage to the Great King is incredible. It is not less incredible, as this scholar writes, that he should have sent the envoys without instructions on the question of earth and water, so no doubt Cleisthenes was careful not to explain to the Assembly the conditions on which the alliance of Persia was to be obtained.

This view is almost commonly supported in the historiography (Gomme, 1944; Gillis, 1969; 1979; Schachermeyer, 1973; Bicknell, 1974; Orlin, 1976; Holladay, 1978; Horsley, 1986; Ostwald, 1988; Arnush, 1995; Berthold, 2002; Cawkwell, 2005). However, M.F. McGregor (1940) challenged this opinion. He convincingly showed referring to Herodotus that the Athenians make two decisions: they sent for Cleisthenes and the other exiles, and, having sent word to recall to Cleisthenes, they dispatch envoys to Persia. Both resolutions, as McGregor considers, were probably voted at a single meeting that makes in fact impossible for Cleisthenes to send envoys.

\section{The Reasons for the First Athenian Embassy to Persia}

There are different explanations of this Athenian diplomatic mission to Persia in the modern historiography. W.W. How and J. Wells (1912) explicitly stated: "The Athenians, presumably their assembly under its democratic leader, are the first to make advances to the Great King, and to invite his intervention in Greece. Naturally they were anxious to preserve their newly won liberties and their independence against the overwhelming power of the coalition arrayed by Sparta against them. Yet it is a shock to find that the chief champion of Hellas against the Mede had first proposed an alliance with him." A. Olmstead (1918) curiously noted, having in mind this episode, that the democracies of Athens and of the other Greek city-states were pro-Persian up to the very outbreak of the Great Persian War. According to A.J. Holladay (1978), the sending of envoys in 508/7 is the first sign of medism under the democracy. Recently R.

M. Berthold (2002) rightly considered that an accusation of medism at this is date wholly inaccurate, since it is only after the Ionian Revolt and Marathon, and especially after Xerxes' invasion, that dealings with Persia take an the aura of treason and betrayal generally associated with the term.

\section{The Result of the First Athenian Embassy to Persia}

In spite of the different approaches to this event most scholars assume that the Athenians had actually concluded an alliance with the Persians (Kuhrt, 1988; Balcer, 1997; Lazenby, 1993; Wiesehöfer, 1996). F. Schachermeyer (1973) even considered that Athens after 508/7 was a city of the Great Kings. A.J. Holladay (1978) points that the envoys may have been given full power to offer earth and water if required, and they were merely very unlucky that the failure of Cleomenes' expedition made this humiliation unnecessary. Some researchers go even further in their speculations on the nature of this alliance and its consequences.

Thus, L. Orlin (1976) writes: "We should now perceive that a fundamental cause of Persian military action against Athens was the latter's violation of her status as treaty-vassal, her action as contract-breaker; the aid which Athens lent to the rebellious Ionian cities was the action of a disobedient vassal who chose to conspire with other disobedient vassals."

Amélie Kuhrt (1988) follows this interpretation. Her arguments may be summarized as follows. Sometime around 507 Athens requested help from the Persians - the first Greek state to try and use the might of the empire to get the better in a conflict with a neighboring state. They offered earth and water as tokens of submission in order to secure an alliance. The contract established by this act was still presumed to be in force some years later both by the Persians and by the Athenians, when (Hdt. 5. 96) Athenian envoys are supposed to have urged the Persian satrap Artaphernes to deter Hippias in his attempt to reestablish himself in Athens. The Persian reply to this was that the Athenians must take the exiled tyrant back. At this point (499) Athens both rejected the Persian demand and joined the lonian revolt by sending an expedition which succeeded in burning Sardis. Whatever the actual course of events might have been, a close relationship between Athens and Persia, broken by the former when it joined the revolt, provides the logical key to the story. Kuhrt further sees the Marathon expedition in this context. She considers that one of the major aims of the Marathon enterprise was certainly to compel Athens to toe the line and acknowledge the Persian King as its overlord, and the defeat suffered by the Persian forces there must have constituted at least one of the justifications (together with treaty-breaking and military aggression) for Xerxes' campaign.

N. Kramer (2004) argued convincingly that the treaty of alliance between Athens and Persia had not been concluded in 508/7. His basic arguments concern the performance of earth and water ceremony. Herodotus (5. 73) tells 
us only that the envoys consented to give earth and water to Artaphernes (they said that they were willing to give), but he does not say that they actually gave these tokens of submission to him. On this occasion the envoys would have carried the earth and water with them from Athens to Sardis and without this the vassalage treaty with the Great King could not have been eventually concluded, however, Herodotus makes it clear that Artaphernes' demand for earth and water seems to have been a surprise for the Athenians and it is hardly possible that they had the earth and water with them at that moment.

Finally the envoys consenting to give the earth and water could be not equated with the exact meaning of these terms (Kelly, 2003; Wiesehöfer, 2004). Furthermore, the conclusion of treaties in Athenian diplomatic practice was usually done on the authority of an Assembly, but not by the envoys themselves (On the ratification of the treaties in the Greek world: Bederman, 2001). Of course, Herodotus may presuppose that the Athenian envoys to Sardis were plenipotentiary (autocratores), that is they were authorized to negotiate a treaty without further ratification of the people, but if they had concluded any agreement with the King, as may be supposed, it could have been repudiated by the Assembly afterwards. D.J. Mosley (1973) concluded that even the plenipotentiary envoys had instructions and were not free from rendering accounts.

So, my conclusion is that there was no treaty between the Athenians and the Great King in 508/7. The promise of earth and water by the Athenian envoys could have misled Artaphernes into waiting for the performance of formal procedure of earth and water giving from the Athenians. As a result the Persians could have seen the Athenians as the King's subordinates and the Athenians otherwise could consider themselves as free of any subordination to Great King of Persia. This somewhat ambiguous situation was resolved only in c. 500, when Hippias son of Peisistratus who had been residing at the Darius' royal court some time before, decided to reinstall himself in Athens, relying on Persian assistance.

\section{The Second Athenian Embassy to Persia}

In 511/0 Hippias who had been an Athenian tyrant since the death of his father Peisistratus was exiled from Athens and fled to Sigeum that was a hereditary possession of the Peisistratids and controlled then by his brother Hegesistratus. Later Hyppias moved to Lampsacus where Aeantis, his nephew, was tyrant and subjected of Darius I (Hdt. 5. 63. 3; 91; 94. 1; cf. Thuc. 6. 59, 3-4).

Herodotus $(5.96 ; 6.102,107-109)$ refers to Hippias' collaboration with the Persians during the period between his flight from Athens and the battle of Marathon. But it is still unclear when Hippias established contacts with the Persians. McGregor (1940) supposed that the exiled tyrant had already resided at Sigeum with Persian consent. M.M. Austin (1990) considers that Hippias had already been building link with Darius as early as C. 514 (hinting possibly at the marriage of Hippias' daughter and Aeantis, the tyrant of Lampsacus).

However, Holladay (1978) dates the beginning of Hippias' relations with the Persians to some later period. He believes that the first episode in Athenian history which has been identified as Medism is the connection formed by Hippias with the tyrant of Lampsacus who, like the other Ionian tyrants, was a vassal of Persia, and thought to be in particularly good standing with the Great King. As Holladay notes it is often suggested that this was a first step by Hippias towards putting himself under the protection of Persia for his own security against his subjects. But this is not what the ancient evidence says. Hippias is said to have been seeking in Lampsacus a refuge to which he could flee if he lost power in Athens, as in fact he eventually did. There is no evidence that Hippias entered into a relationship with Persia at this time.

Holladay writes that this development is specifically placed at a later time when the Spartan plan to restore him to Athens had failed through Corinthian opposition (Hdt. 5. 96). It was only when all his hopes within Greece had failed that Hippias turned to Persia, as Herodotus states quite clearly, and from then on Persia made his restoration the price of any relationship with Athens. Holladay rightly supposes that when the Athenian envoys went to Persia in 508/7 the only Persian demand we hear of was for earth and water, there was no mention of Hippias at that time. Meanwhile Holladay's interpretation of Hippias' actions needs to be corrected.

Other scholars are also right in supposing that Hippias' actions in regard to Asia Minor were due to his intention to establish contact with the Persians. He could have resided at Sigeum with the consent of Artaphernes and moved to Lampsacus seeking for advances to Darius. When Hippias had traveled to Susa from Sparta c. 504, he began to agitate at the King's court against his fellow Athenians. Only then did Darius dispatch his orders to Artaphernes to reinstall Hippias in Athens and this forced the Athenians to send their envoys to Sardis again. Herodotus (5. 96) says of this second Athenian embassy:

"Hippias, having come from Lacedaemon into Asia, left no stone unturned, maligning the Athenians to Artaphrenes, and doing all he could to bring Athens into subjection to himself and Darius. While Hippias was engaged in 
these activities, the Athenians heard of it and sent messengers to Sardis, warning the Persians not to believe banished Athenians. Artaphrenes, however, bade them receive Hippias back, if they wanted to be safe. When his words were brought back to the Athenians, they would not consent to them, and since they would not consent, it was resolved that they should be openly at war with Persia" (translation by A.D. Godley).

B.D. Merrit (1939) notes about Herodotus' description of the Athenian second embassy to Sardis: "The significance of this passage in Herodotus has never been full understood. It implies that the Athenians were on good terms with Persia and that they were interested in maintaining friendly relations."

\section{The Result of the Second Athenian Embassy to Persia}

Herodotus (5. 97. 1-3) says that it was when the Athenians were already on bad terms with Persia that Aristagoras the Milesian came from Sparta to Athens. Coming before the people, Aristagoras spoke of the good things of Asia, and how the Persians could easily be overcome. This he said adding that the Milesians were settlers from Athens. The Athenians, now persuaded, voted to send twenty ships to aid the Ionians, appointing as their commander Melanthius.

Herodotus (5. 97. 3) characterizes Melanthius as man who had an unblemished reputation. He was a candidate for exile on one of ostrakophoria in 480s. (Brenne, 2002) and it may be connected with his role in the lonian enterprise of the Athenians. Some scholars consider that the small number of ships sent was probably the result of compromise, and that the withdrawal at the end of the first campaign was due to a desire to be quit of the whole affair and so to avoid, as possible, a direct conflict with Persia. Herodotus (5. 97. 3) says that these ships were the beginning of troubles for both Greeks and barbarians The Athenian fleet was accompanied by five or six ships from Eretria commanded by Eualkides (Hdt. 5. 102; Hellanic. FGrH 4. F. 183 = Plut. De Her. malign. 869a; Ephor. FGrH 70. F. 187).

Though the Athenians shortly called back their ships the Eretrians continued to fight, probably until the final defeat of the Ionian revolt (Lysanias of Mallus: FHG IV. F. 1). K.G. Walker (2003) suggests that in fact the twenty Athenian ships were troop transports bringing Athenian hoplites that would fight at Sardis and that the Eretrian triereis were convoying them while the main Eretrian war fleet was in the south conducting naval operations designed to prevent the movement of the Persian king's ships northward, bringing reinforcements to his land troops.

But after the battle of Ephesus in 498 the Athenians wholly separated themselves from the lonians and refused to aid them, although Aristagoras sent messages of earnest entreaty (Hdt. 5. 102-103). Herodotus makes the Athenian people responsible for the decision to aid to the Ionians, not just certain politicians, stating that it is easier to deceive many than one, for Aristagoras could not deceive Cleomenes of Lacedaemon, one single man, but thirty thousand Athenians he could. In this Herodotus is probably right. Earlier the people (but not Cleisthenes!) had sent envoys to Sardis seeking for the alliance with Persia and in changed circumstances now the Athenians voted to aid the rebellious Ionians and shortly afterwards to cease their aid. The Athenians' decision to help the Ionians may be clear and does not require further discussion.

But why did the Athenian fleet abandon them and return home from Asia? It is unlikely, as some scholars argue, that there were in Athens at that time factions which determined Athenian foreign policy towards the Persians. The shift in the Athenians' attitude towards the Ionian revolt may be due to developments in the internal situation in Athens that were determined by the struggle between pro-Persian and anti-Persian parties, or individuals (Robinson, 1939; 1945; McGregor, 1940). It is considered that the election of Hipparchus son of Charmos as archon in 497/6 (Dion. Hal. AR. 5. 77. 6; 6. 6. 1; Cadoux, 1948), and the Athenians' calling back their ships from Asia may be related (Karavites, 1977). The explanation of the inconsistent Athenian policy may be very simple, as it is not difficult to imagine that rumours were spread in Athens that Darius took a final decision at this moment to wage war against the Athenians. It could have been this information, which Herodotus (5. 105) reports thus:

"When it was reported to Darius that Sardis had been taken and burnt by the Athenians and Ionians and that Aristagoras the Milesian had been leader of the conspiracy for the making of this plan, he at first, it is said, took no account of the lonians since he was sure that they would not go unpunished for their rebellion. Darius did, however, ask who the Athenians were, and after receiving the answer, he called for his bow. This he took and, placing an arrow on it, and shot it into the sky, praying as he sent it aloft, "O Zeus, grant me vengeance on the Athenians." Then he ordered one of his servants to say to him three times whenever dinner was set before him, "Master, remember the Athenians." (translation by A.D. Godley).

That would be why the Athenians considered the Persian Empire as the most powerful in the world and preferred to avoid direct confrontation with Darius. 


\section{Conclusion}

To conclude the Athenians attempted to establish the relations with the Achaemenid Empire that had been considered the most powerful realm in the East as early as 508/7. It was due to the threat of Spartan invasion of Attica on the eve of the great reforms of Cleisthenes the Athenian.

The first Athenian embassy to Persia that had intended to get the Persians as the allies was not successful because the Athenian delegates were faced with the Persian demand for subjugation (earth and water). The Athenians primarily have agreed to the Persian terms but later they rejected them. As a result, the Athenian-Persian relations have been strained since that time.

The problem of ex-Athenian tyrant Hippias was next reason for further negotiations between the Athenians and the Persians ca 500 B.C. The incapability of the Second Athenian Embassy to come to understanding with the Persians about Hippias' status led to the Athenian decision to interfere into the Ionian revolt in the Achaemenid Empire. This decision meant the declaration of war between Athens and Persia and became a prologue to the greater Greco-Persian Wars.

\section{Acknowledgements}

I would like to thank Dr. Philip De Souza (University College, Dublin, Ireland) for the most helpful comments to earlier draft of this text and for correction of my English in it.

\section{References}

Arnush, M.F. (1995). The Carrier of Peisistratos Son of Hippius, Hesperia, 64 (2), 135-162.

Austin, M.M. (1990). Greek Tyrants and the Persians, Classical Quarterly, 40 (3), 289-306. http://dx.doi.org/10.1017/S000983 8800042889.

Balcer, J.M. (1997). The Persian Conquest of the Greeks 545-450 B.C. (p, 158-159). Konstanz: XENIA. Konstanzer Althistorische Vortrage und Forschungen.

Bederman, D.J. (2001). International Law in Antiquity (pp.171-173). Cambridge: Cambridge University Press. Retrieved from http://catdir.loc.gov/catdir/samples/cam031/00033672.pdf

Berthold, R.M. (2002). The Athenian Embassies to Sardis and Cleomenes' Invasion of Attica, Historia 51 (3), 259-267.

Bicknell, P. (1974). Athenian Politics and Genealogy: Some Pendants, Historia, 23 (2), 146-163.

Brenne, S. (2002). Die Ostraka (487-ca.416 v.Chr.) als Testemonien (T.1.), In P. Siewert (Ed.), Ostrakismos - Testimonien. Die Zeugnisse antiker Autoren, die Inschriften ond Ostraka über das athenische Scherbengericht aus vorhellenistischer Zeit (487322 v. Chr.) (pp. 87-89). Stuttgart: Franz Steiner Verlag.

Briant, P. (2002). From Cyrus to Alexander: A History of the Persian Empire (p.139-161). Winona Lake, Indiana: Eisenbrauns.

Cadoux, T.J. (1948). The Athenian Archons from Kreon to Hypsichides, Journal of Hellenic Studies, 68, 70-123. http://dx.doi.org/10. $2307 / 626301$.

Cawkwell, G.L. (2005). The Greek Wars. The Failure of Persia (p. 53). Oxford: Oxford University Press.

Cook, J.M. (1985). The Rise of the Achaemenids and the Establishment of their Empire, Cambridge History of Iran (vol. 2, pp. 200-291). Cambridge: Cambridge University Press. http://dx.doi.org/10.1017/CHOL9780521200912.007.

Gillis, D. (1969). Marathon and Alcmaeonids, Greek, Roman and Byzantine Studies, 10 (2), 133-145.

Gillis, D. (1979). Collaboration with the Persians (p. 48). Wiesbaden: Franz Steiner Verlag.

Gomme, A. (1944). Athenian Notes, American Journal of Philology 65 (3), 321-322. DOI: 10.2307/290661.

Graf, D. (1985). Greek Tyrants and Achaemenid Politics, In J.W. Eadie \& J. Ober (Eds), The Craft of the Ancient Historian. Essays in Honor of Chester G. Starr. Lanham: University Press of America, 79-123.

Holladay, A.J. (1978). Medism in Athens 508-480 B.C., Greece \& Rome 25 (2), 174-191. http://dx.doi.org/10.1017/S0017383 500020301.

Horsley, G.H.R. (1986). Kleisthenes and the Abortive Athenian Embassy to Sardis, Museum Philologum Londiniense, 7, 99-105.

How W.W. and Wells J. (1912). A Commentary on Herodotus (vol.1, p. 40). Oxford: Oxford University Press.

Karavites, P. (1977). Realities and Appearance, 490-480 B.C., Historia, 26 (1), 129-147.

Kelly, T. (2003). Persian Propaganda - A Neglected Factor in Xerxes' Invasion of Greece and Herodotus, Iranica Antiqua, 38, $173-219$. DOI: 10.2143/IA.38.0.139.

Kramer, N. (2004). Athen - keine Stadt des Grosskönigs!, Hermes, 32, 257-270.

Kuhrt, A. (1988). Earth and Water, In A. Kuhrt \& H. Sancisi-Weerdenburg (Eds), Achaemenid History (vol. 3, pp. 87-99). Leiden: Nederlands Instituut Voor Het Nabije Oosten.

Lazenby, J.F. (1993), The Defence of Greece, 490-479 B.C. (p. 42). Warminster: Aris and Phillips.

Luraghi, N. (1998). Un Gran Re e I tiranni. Per una volutazione storica delle tirannida in Asia Minore durante il regno dei primi Achemenidi, Klio 80 (1), 22-46. DOI: 10.1524/klio.1998.80.1.22. 
McGregor, M. F. (1940). The Pro-Persian Party at Athens from 510 to 480 B.C., Athenian Studies Presented to W.S. Ferguson (Harvard Studies in Classical Philology, Supplementary Volume I), 71-95.

Merrit, B.D. (1939). Greek Inscriptions (14-27), Hesperia, 8 (1), 48-82.

Meyer, E. (1958). Geschichte des Altertums, 3 (p.741). Darmstadt: Wissenschaftliche Buchgeseeschaft.

Mosley, D.J. (1973). Envoys and Diplomacy in Ancient Greece (p. 36). Wiesbaden: Franz Steiner Verlag.

Munro, J.A.R. (1899). Some Observations on the Persian Wars, Journal of Hellenic Studies, 19, 294-332. http://dx.doi.org/10.2307/ 623932.

Olmstead, A.T. (1918). Oriental Imperialism, American Historical Review, 23, 755-762. DOI: 10.2307/1836330.

Orlin, L.L. (1976). Athens and Persia ca 507 B.C.: A Neglected Perspective, In L.L. Orlin et al. (Eds). Michigan Oriental Studies in honor of G.G.Cameron (p. 264), Ann Arbor: University of Michigan.

Ostwald, M. (1988). The Reform of the Athenian State by Cleisthenes, Cambridge Ancient History (2nd ed., vol. 4, pp. 303-346). Cambridge: Cambridge University Press. http://dx.doi.org/10.1017/CHOL9780521228046.012.

Petit, T. (1985). L'intégration des cités ioniennes dans l'empire achéménide (Vle siècle), Revue des Études Anciennes, 87, 43-52.

Robinson, C.A. (1939). The Struggle for Power at Athens in the Early Fifth Century, American Journal of Philology, 60, 232-237. DOI: $10.2307 / 290661$.

Robinson, C.A. (1945). Athenian Politics, 510-486 B.C. American Journal of Philology, 66, 243-254. DOI: 10.2307/290661.

Schachermeyer, F. (1973). Athen als Stadt des Grosskönigs, Grazer Beiträge, 1, 211-220.

Walker, E.M. (1930). Athens: The Reforms of Cleisthenes, in Cambridge Ancient History (vol. 4, pp. 137-172). Cambridge: Cambridge University Press.

Walker, K.G. (2003). Archaic Eretria. A Political and Social History From the Earliest Times to 490 B.C. (p.274, 277). London: Routledge. Wiesehöfer, J. (1996). Ancient Persia from 550 B.C. to 650 A.D. (p. 3). London: I.B. Tauris.

Wiesehöfer, J. (2004). 'O Master, Remember the Athenians': Herodotus and Persian Foreign Policy, In V. Karageorgis \& I. Taifacos (Eds.). The World of Herodotus. Nicosia: Leventis Foundation, 209-221.

Young, T.C. (1988). The Consolidation of the Empire and its Limits of Growth under Darius and Xerxes, in Cambridge Ancient History (2nd ed., vol. 4, pp. 53-111). Cambridge, Cambridge University Press. http://dx.doi.org/10.1017/CHOL9780521228046.003. 